\title{
Estimating the Cost-Competitiveness of Recycling-Based Geopolymer Concretes
}

\author{
Annastiina Rintala ${ }^{1, * \mathbb{D}}$, Jouni Havukainen ${ }^{2}$ and Mariam Abdulkareem ${ }^{2}$ \\ 1 Department of Industrial Management, LUT University, 53850 Lappeenranta, Finland \\ 2 Department of Sustainability Science, LUT University, 53850 Lappeenranta, Finland; \\ jouni.havukainen@lut.fi (J.H.); mariam.abdulkareem@lut.fi (M.A.) \\ * Correspondence: annastiina.rintala@lut.fi
}

Citation: Rintala, A.; Havukainen, J.; Abdulkareem, M. Estimating the Cost-Competitiveness of

Recycling-Based Geopolymer Concretes. Recycling 2021, 6, 46 https://doi.org/10.3390/ recycling 6030046

Academic Editors: José Neves and Ana Cristina Freire

Received: 25 May 2021

Accepted: 2 July 2021

Published: 5 July 2021

Publisher's Note: MDPI stays neutral with regard to jurisdictional claims in published maps and institutional affiliations.

Copyright: (c) 2021 by the authors. Licensee MDPI, Basel, Switzerland. This article is an open access article distributed under the terms and conditions of the Creative Commons Attribution (CC BY) license (https:// creativecommons.org/licenses/by/ $4.0 /)$.

\begin{abstract}
The cement industry is a major contributor to greenhouse gas emissions on a global scale. Consequently, there has been an increasing interest, in both academia and business, in low-carbon concretes in which Ordinary Portland Cement (OPC) is partially or fully replaced with industrial side streams. However, the realization of the environmental benefits of such materials depends on how competitive they are in the construction market, where low costs are a major competitive factor. This is not straightforward, as many types of concretes exist. Raw material prices vary, and costs can be influenced by governmental regulations via carbon pricing. This study presents a case study estimating the cost prices of four different geopolymer concretes with different material compositions and carbon footprints, considering the raw material price variability and the potential impact of carbon emissions regulation (carbon price). The case study demonstrates how material mix cost comparisons can be made openly and systematically. The results imply that carbon pricing, at the rates currently applied, does not significantly change the cost price difference between traditional and geopolymer concretes. Instead, cost-competitiveness of low carbon concretes depends heavily on the material mix type and the availability of critical side streams.
\end{abstract}

Keywords: recycling; concrete; costs; carbon footprint; carbon price

\section{Introduction}

Concrete production generates approximately $8.6 \%$ of all carbon dioxide emissions worldwide [1], and a considerable amount of this comprises cement production. Each tonne of Ordinary Portland Cement (OPC) produced requires 60-130 kg of fuel oil or its equivalent, depending on the cement variety and the process used, and about $110 \mathrm{kWh}$ of electricity. This accounts for around $40 \%$ of the average 0.9 tonnes of $\mathrm{CO}_{2}$ emissions per tonne of cement produced, while the rest are attributed to the calcination process, other manufacturing processes, and transportation [2].

Due to this environmental concern, many studies have been devoted to the partial or complete replacement of cement in concretes. Utilizing fly ash and other by-products of the energy and minerals industry as supplementary cementitious material in cement (or as a raw material in cement-free binders, referred to as geopolymers in the literature) holds a considerable potential in lowering the carbon footprint of concrete. It is often mentioned that geopolymer binders have been shown to potentially reduce carbon dioxide emissions associated with the manufacturing of cement by up to $80 \%$ [3].

However, the actual sustainability benefit of low-carbon materials depends on the scale to which their manufacture and use can be put into practice. Economic feasibility has been among the major factors hindering the scale-up of geopolymer concrete in the markets. Carbon pricing, an increasingly used form of regulation, is a potential means for promoting low-carbon solutions, and in principle, it could level the cost price difference between traditional and low-carbon concretes. This induces the following research question: What is the cost-competitiveness of geopolymer concrete, and how can it be assessed? 
This study approaches this question by presenting a case study estimating the economic feasibility of four new recycling-based geopolymer concrete mixes. The approach includes gathering raw material price information, calculating price ranges for material mixes, and adding the impact of potential carbon pricing scenarios to the model using life cycle assessment (LCA) data. The model provided by this study can be used to support decision-making alongside material development to assess the cost-competitiveness of low-carbon concrete mixes.

\subsection{Recycling-Based Low-Carbon Concretes}

The $\mathrm{CO}_{2}$ emissions and their mitigation approaches in the cement industry have been a subject of numerous studies $[4,5]$, and according to the estimates published by Cembureau [6], the amount of $\mathrm{CO}_{2}$ emitted from cement production has dropped from $783 \mathrm{~kg} / \mathrm{t}$ (1990) to $667 \mathrm{~kg} / \mathrm{t}$ (2017) and could be reduced to $571 \mathrm{~kg} / \mathrm{t}$ by 2030 by making use of various means, such as energy efficiency solutions, low-carbon fuels, clinker substitution, and carbon capture and storage. This study focuses on clinker or cement substitution with side streams.

Overall, the carbon footprint-reducing effect of side stream usage is based on the fact that in LCA studies, it is an extensive practice to assume that waste does not carry environmental impacts from the previous life cycle phases. This suggests that waste's life cycle begins from waste generation, for example, when it is disposed into a bin. This is defined as the zero-burden approach [7]. Thus, the environmental impacts of the secondary raw materials, such as industrial side streams or waste, are allocated to the primary production chains (i.e., to the main products and by-products, not the waste; [8]).

Side streams can be used as supplementary cementitious materials (SCMs) with OPC, or as precursors in other binder types that are used in alkali-activated concretes. Alkali-activated concretes (AACs) are synthesized by reacting an alkali silicate/alkali hydroxide solution with an aluminosilicate powder and water [9]. SCMs, such as fly ash or ground granulated blast furnace slag (GGBS) with a high $\mathrm{Si} / \mathrm{Al}$ ratio, can be used as source materials (aluminosilicate). Allthough in many cases, "alkali-activated material" may be a more correct term, the term "geopolymer concrete" is used generally in academic literature and in business for concretes that are produced without grounded clinker (burned limestone). The same side streams can be utilized in many cement/binder types; therefore, the suitable side streams can be referred to generally as binder precursors.

Aluminosilicates in geopolymer mixes comprise mainly slags, ashes, and metakaolin. The majority (65\%) of geopolymer mix designs in studies are based on fly ash, followed by fly ash/slag (12\%), metakaolin (10\%), and slag (6\%) [10]. Alkali activators generally comprise alkali hydroxides (e.g., $\mathrm{NaOH}, \mathrm{KOH}$ ) and alkali silicates (e.g., $\mathrm{Na}_{2} \mathrm{SiO}_{3}, \mathrm{~K}_{2} \mathrm{SiO}_{3}$ ), individually or in combination.

Aggregates, another basic component of concrete, are traditionally sand and gravel. Generally, aggregates are not chemically involved in the structure's formation, but their packaging affects the resulting structure's properties. Therefore, it is imperative that the grain size distribution is correct. In addition to sand and gravel, sand-like and gravel-like substances may be used, for example, tailings [11], recycled concrete [12], granulated fly ash [13], and municipal waste incineration bottom slag [14]. Very small grain aggregates are called fillers, and some have structural strengthening properties. Most frequently, granular fillers are used for this purpose, such as special mineral sands or fumes and ground ceramic products [15].

Geopolymer concretes are known to have a longer service life than traditional OPC concrete, because geopolymer-based materials possess good mechanical strengths [16], a high resistance against chemical attack [17], and a high temperature resistance [18]. Notably, in the literature, geopolymer concrete is often compared against CEM I-type OPC concrete [19-22]; however, there are different concrete types that can be considered traditional, because they follow the cement standard. 
Different cement classes defined in the standard are presented in Table 1. If it is assumed that $15 \%$ of concrete is cement, $5 \%$ water, and $80 \%$ recycled aggregates (a typical mix for $20 \mathrm{MPa}$ compressive strength), it is possible to achieve a $94 \%$ recycling rate within the current cement standard.

Table 1. Classification of cement types according to cement standard, adapted from [23].

\begin{tabular}{cc}
\hline Cement Type & Description \\
\hline CEM I Portland cement & Portland cement and up to 5\% of minor additional constituents (the original OPC) \\
CEM II Portland composite cement & Portland cement with up to 35\% of other SCM, such as ground limestone, fly ash, or GGBS \\
CEM III blast furnace cement & Portland cement with a higher percentage of blast furnace slag, up to 95\% \\
CEM IV pozzolanic cement & Portland cement with up to 55\% of selected pozzolanic constituents \\
CEM V composite cement & Portland cement blended with GGBS or fly ash and pozzolanic material \\
\hline
\end{tabular}

Side stream-based binder precursors can be divided into already recognized materials in cement standard, such as silica fume, coal fly ash, and blast furnace slag. Additionally, there are other slags and ashes suitable for geopolymer purpose but are unrecognized in cement standard. Examples are bauxite residual from alumina production-also known as red mud [24] - and waste from mining and processing copper ore [25]. Furthermore, some consumer wastes and separate fractions of demolition waste, such as scrap glass [26], ceramic waste [15], and mineral wool [27], have shown potential for geopolymer purpose. There are studies that have replaced commercial alkali activators with recycling-based material [28,29]; however, this has not been implemented on an industrial scale.

\subsection{The Markets of Low-Carbon Concretes}

Currently, geopolymer concrete utilization is limited in construction, and a few reasons have been found for this: (1) current material standards hinder the acceptance of geopolymers (2) the availability of industrial side streams varies by location, as do the volumes and qualities of side streams; and (3) the costs of geopolymer production easily exceed the costs of OPC production [3]. Furthermore, several studies have discussed additional barriers, such as the development of suitable admixtures, required operator skill at batch plants, capital intensive setup of processing facilities, lack of long-term durability data, particularly field performance, and the development of appropriate test methods [30].

Despite these barriers, there are various reported examples of the manufacturing of geopolymer concrete products around the world. The case studies are often pilots, but there are also companies currently manufacturing geopolymer concrete materials or products (Renca, Wagners, Kiran Global Chem, Zeobond, Geopolymer Solutions, GeoMITS, Alchemy Geopolymer Solutions, and SQAPE Technology).

Geopolymer concrete has been used as a surface material in roads and fields. Examples can be found in pedestrian routes and cycling paths, e.g., in the Netherlands [31] and Australia, as well as heavy traffic roads in Russia [32]; fields, such as container fields in Johannesburg and wind power parks in Loeriesfontein, South Africa; airport runways, e.g., during the Persian Gulf War (hybrid OPC/geopolymer concrete) [33] or in Australia [34]. Geopolymer concrete has also been applied in repairing similar structures [35].

Another application area is housebuilding and industrial construction. Multi-story houses have been built in Russia, Poland, and China, with earliest known examples dating back to the 70s [32]. In agriculture, geopolymer concrete has been used in silo building; it is considered a hygienic material [32]. The material has also been applied to parts of buildings, such as floors in industrial buildings [31], masonry tiles and roof tiles [32], and composite panels [36]. It can also be applied in mortar or underlayment and in coating material, e.g., for corrosion protection and fire protection [37] or waterproof pool coating [38].

Due to its waterproof properties and durability, one area of application is structures that are closely connected with water, such as piers [39] and boat ramps [40], water construction in general [41], fountain structures, sewage pipes and other sewage structures [32], and the repair of the such facilities [42]. 
Furthermore, geopolymers are used in earth construction, where the strength requirements are considerably lower than in building construction [43]. Overall, the geopolymer concretes compete on the same markets as the traditional concretes. Although there is some attention to special applications, such as refractory concrete or acid-proof concrete, there are also similar products in the markets that are manufactured with current cement standards.

\subsection{Price-Estimations Concerning Low-Carbon Concretes}

When compared with OPC concrete, geopolymer concrete is usually more expensive, but slightly cheaper in some cases. Habert and Ouellet-Plamondon [44] compared the economic allocation of one-part geopolymers and discovered that they couldachieve an $80 \%$ reduction in costs compared with OPC. Yand et al. [19] concluded that the cost of their one-part alkali-activated BFS foamed concrete was slightly higher, by 1.0-1.11 times, than that of OPC concrete. Chan, Thorpe, and Islam [20] estimated the material and manufacturing costs for over 20 years of fly ash-based geopolymer cement and OPC and concluded that geopolymers would be $18 \%$ more expensive. McLellan et al. [45] estimated the production costs of four typical Australian geopolymer pastes and concluded that in one case the manufacturing costs were $7 \%$ lower, but in other cases they were up to $39 \%$ higher compared with OPC. Vilamová and Piecha [21] estimated that the material cost of fly ash-based concrete is twice the cost of OPC concrete. Ostwal and Chitawadagi [22] estimated the production costs of GGBS and fly ash-based geopolymer concrete blocks to be higher than those of traditional cement concrete blocks.

Notably, the cost comparisons presented above are not generally comparable because they have not been standardly performed. There is variation in which costs are considered in the cost estimations, in the used mix designs, and in the prices of used ingredients. However, studies have provided many distinct geopolymer concrete mixes, among which 125 formulations of geopolymer-based materials have been reported in recent reviews [46-49]. The reported mix designs offer a basis for estimating cost price ranges for geopolymer concretes.

\subsection{Carbon Pricing}

To reduce and mitigate carbon emissions, some national and international authorities have adopted carbon emissions regulation practices to encourage polluters to reduce the volume of greenhouse gases they emit into the atmosphere. The method usually takes the form of either a carbon tax or a requirement to purchase permits to emit, generally known as carbon emissions trading or "cap and trade."

A carbon tax is a tax levied on the carbon content of fuels. The term carbon tax is also used to refer to a carbon dioxide equivalent tax. The principle of cap and trade is as follows: in the European Union Emissions Trading Scheme (EU ETS), the European Commission determines the maximum amount of emissions allowed for each trading period corresponding to the total pot of allowances. This total amount is distributed to the various member states, whose national emissions trading authorities allocate a countryspecific quota to industrial and energy production plants. The total amount is smaller than the current European Union (EU) emissions. Thus, not all companies involved in emissions trading can continue producing emissions as before. It is therefore profitable for some companies to reduce their emissions, and thus sell the released allowances to others in need.

The EU ETS is the largest multi-national greenhouse gas emissions trading scheme in the world. Phase I began operation in January 2005, with all 15 EU member states participating. The program caps the amount of carbon dioxide that can be emitted from large installations with a net heat supply in excess of $20 \mathrm{MW}$, such as power plants and carbon intensive factories. Currently, there are around 600 plants in Finland covered by carbon emissions trading. By 2019, over 40 countries, including Finland, had implemented carbon taxes. In Finland, $\mathrm{CO}_{2}$ tax is included in fuel tax. 


\subsection{Prices of Carbon Allowances and Carbon Taxes}

Carbon's prices have varied over time and place. Figure 1 presents some examples of carbon's prices and provides a preliminary perspective of the potential price range for the carbon emissions. Currently (28 September 2020), the Swedish carbon tax represents the highest carbon price worldwide. Notably, prices are not necessarily comparable between carbon pricing initiatives due to differences in the number of sectors covered and allocation methods applied, specific exemptions, and different compensation methods.

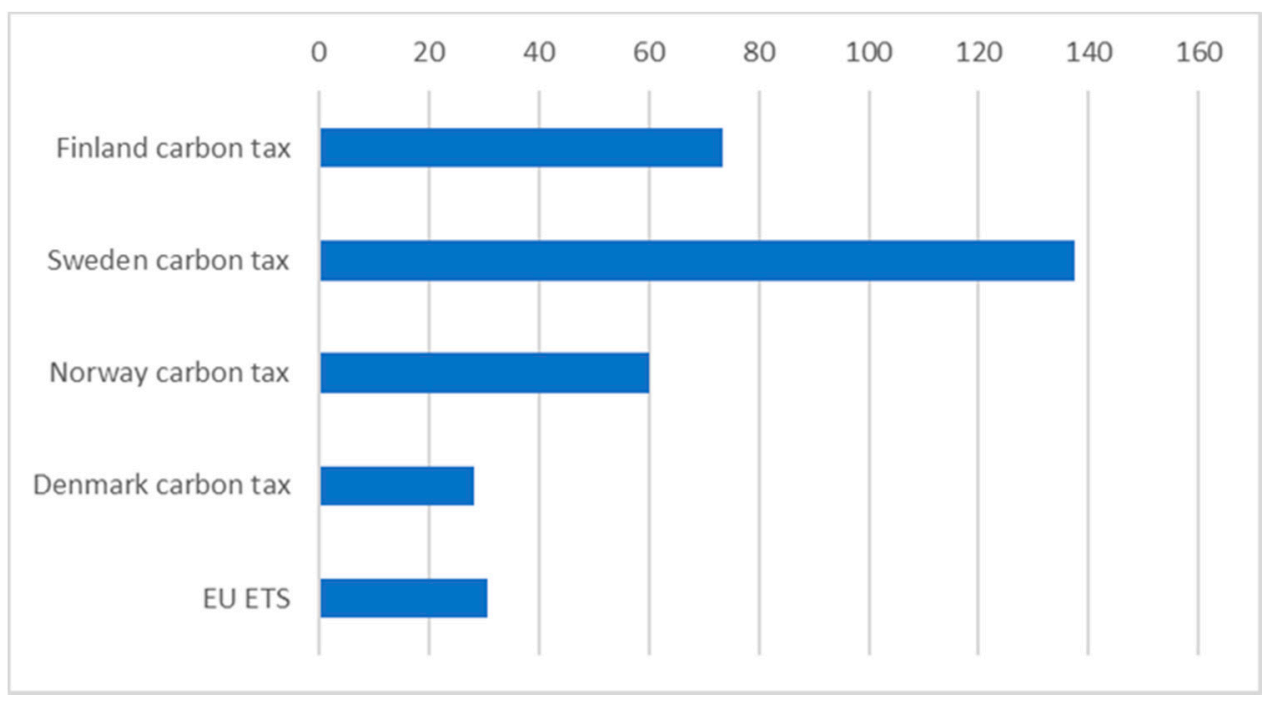

Figure 1. Examples of carbon prices [US\$/ $\left.\mathrm{tCO}_{2} \mathrm{e}\right]$, data from [50] (ETS: Emissions Trading System).

Despite the current policies and prices, it is also common practice-in American corporations - to calculate an "internal price on carbon." This internal price is calculated to assess the risk value of future projects when making economic investment decisions if the assets have a long lifespan and can be affected by energy policies in the future. The prices range from USD 6-7 per tonne of carbon dioxide at Microsoft to USD 60 per tonne at Exxon Mobil [51].

In the literature, carbon emission regulation has inspired many modeling studies that concern, for example, supply chain design and management [52-58]. The potential impact of carbon emissions regulation should also be noted in different contexts, including the construction context, but this has not yet received similar attention in the literature.

\section{Results}

This section presents the results of the material price search, cost-price estimates for concrete mixes, and analysis of the impact of carbon pricing on the cost-price differences between different material mixes. In addition, the generalizability of the cost estimation approach is discussed.

\subsection{Estimates of Material Purchase Prices}

On the Alibaba.com website, different suppliers report the price range of their products. The suppliers came from 36 countries, the majority from China (Figure 2). The price range may depend on both the purchase volume and the quality of the product. Figure 3 presents a summary of the price search. The number of options, $\mathrm{N}$, mainly indicates the number of suppliers, but in some cases, the supplier sells the same material in different qualities, so it increases the number of options. The lower boundary of the price range was calculated as the average of the lower boundaries informed by the suppliers, and the upper boundary was calculated in an analogous manner. 


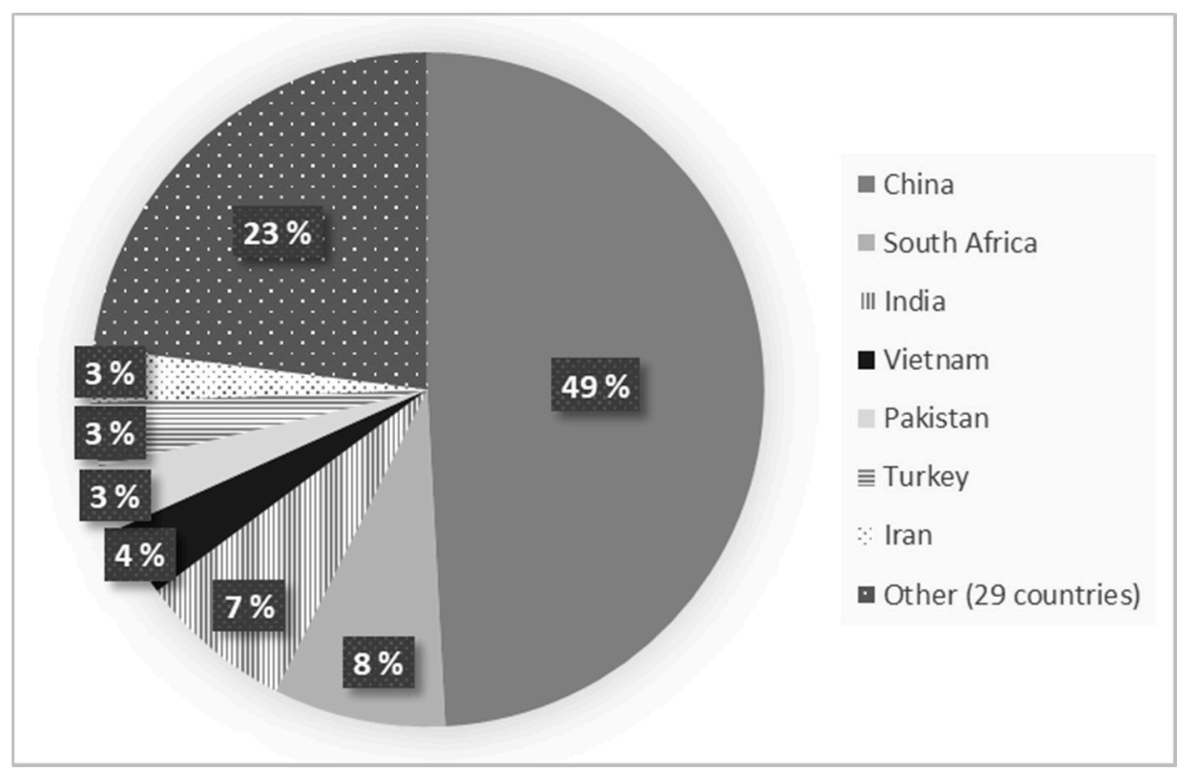

Figure 2. Concrete material supplier distribution by country in Alibaba.com, April 2019.

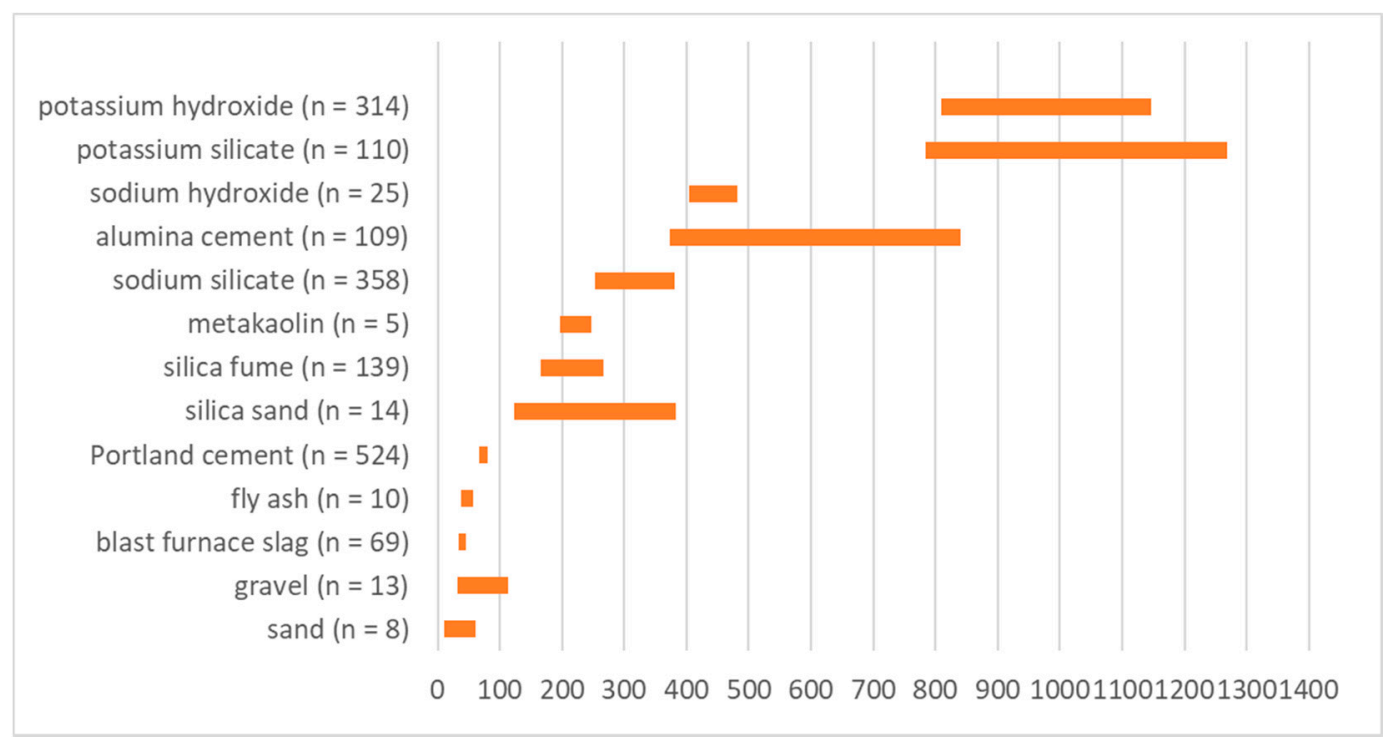

Figure 3. Average price ranges for the prices of different concrete raw materials in Alibaba.com in April 2019 [USD/t] n: number of options.

The price search focused on materials that were used in geopolymer concrete mixes in the case project, or in typical geopolymer concrete mixes presented in the literature. It should to be noted that all possible geopolymer concrete raw materials are not sold on open markets; therefore, the price information is not available.

For example, in the case of this project, the utilization of various local ashes and slags as aggregate was considered. Due to disposal fees, these side streams have a negative price in principle, but the required processing (e.g., drying and sieving) significantly increases their cost price. A large part of the processing costs consists of fixed costs; therefore, it is difficult to estimate the potential unit price for the processed material. Instead, a reference price was used, which was the price of the nearest commercial equivalent. This must be understood as a lowest possible price (range) for the material considered.

Notably, for Portland cement, the price range is relatively narrow despite the high number of suppliers; however, in the case of some ingredients of geopolymer concrete, especially for alkali activators (potassium/sodium hydroxide/silicate), the price range 
is wide. This is partly explained because these are sold in different forms (solid/liquid), grades, and in different purities. This makes it more difficult to estimate the actual possible prices of geopolymer concretes, whereas for traditional concrete, it is easier to estimate a reference price.

For gravel and sand, Alibaba.com does not seem to offer prices that are competitive with those offered by local suppliers in Finland. During the case project, such reference prices such as $5-10 € / \mathrm{m}^{3}$ for sand and gravel were discussed. However, the search results implied that in some other geographical areas, high-quality sand and gravel may have a higher selling price.

In this price search, it seemed that typical aluminosilicates-coal fly ash and blastfurnace slag-showed lower selling prices than Portland cement. All the suppliers of coal fly ash were from India, except one from Pakistan, and almost all suppliers of blast furnace slag were from China. It is difficult to ascertain only based on these data whether the quality of the ash and slag sold is suitable for binder manufacturing, but if so, their use as SCMs can lower the cost price of concrete. However, the relationship between demand and supply affects the selling price of the material. For example, in Finland, the prices of these materials are considerably higher; $110 \mathrm{EUR} / \mathrm{t}(134 \mathrm{USD} / \mathrm{t})$ for blast furnace slag and $70 \mathrm{EUR} / \mathrm{t}$ (85 USD/t) for coal fly ash. In Finland, there is only one blast furnace, and coal fly ash has recently vanished from open markets due to poor availability. The open availability of critical side streams by location can be considerably estimated in studies that compare production and utilization volumes. For example, a considerable volume of unutilized crude steel slag has been noticed in China [59], and the same applies to coal fly ash [60]. Naturally, the utilization rates, which imply the prices, are not stable. Silica fume, a by-product of producing silicon metal or ferrosilicon alloys, is an example of a material that has turned from waste to a high-value product. Although once cheap, it is now an expensive high-performance cement supplement primarily used in bridges and other exposed structures that require high weathering performance [2].

In most concrete applications, the concrete material needs to be reinforced. In the reinforced geopolymer mixes presented in the literature [61-69], the amount of fiber is $19-156 \mathrm{~kg} / \mathrm{m}^{3}$ for steel fiber and $0.3-33 \mathrm{~kg} / \mathrm{m}^{3}$ for other fibers (glass fiber, polypropylene fiber, and polyvinyl alcohol fiber). The amount of reinforcement needed is assumed to depend heavily on the application of concrete. In the case project, the amount of fiber mixed was $3-4 \mathrm{~kg} / \mathrm{m}^{3}$ when the concrete was used for noise-barrier elements. Example prices for reinforcement materials are presented in Table 2. Although the prices USD/t are high, they do not have a significant effect on the cost price of the material if the quantity is as small as in the case.

Table 2. Price ranges for concrete reinforcement materials from Alibaba.com (USD/t).

\begin{tabular}{cc}
\hline Concrete Reinforcement Material & Price \\
\hline Steel Fiber & $698-1300 \mathrm{USD} / \mathrm{t}$ \\
Polypropylene fiber & $1699-2699 \mathrm{USD} / \mathrm{t}$ \\
Glass fiber & $540-1500 \mathrm{USD} / \mathrm{t}$ \\
Polyvinyl alcohol fiber & $1999-2999 \mathrm{USD} / \mathrm{t}$ \\
Basalt fiber & $2200-2800 \mathrm{USD} / \mathrm{t}$ \\
\hline
\end{tabular}

\subsection{Cost Price Estimates for Example Mixes}

Table 3 shows five mix compositions, and Table 4 shows their compressive strengths. Mix 0 represents a typical OPC concrete mix that can be used in construction. Other mixes are geopolymer concrete mixes. Mix 1 is a castable mix, and 2,3, and 4 are 3Dprintable mixes, all developed in the case project. For confidentiality, the mix designs are not revealed in more detail, but similar type (3D printable) geopolymer concrete mixes have been presented in the literature [70-72]. 
Table 3. Proportions of the different material mixes.

\begin{tabular}{cccccc}
\hline Constituent & Mix 0 & Mix 1 & Mix 2 & Mix 3 & Mix 4 \\
\hline Cement & $27 \%$ & & & & \\
Calcium aluminate cement & & & & $4 \%$ & \\
Activator & & $10 \%$ & $15 \%$ & $19 \%$ & $0.3 \%$ \\
Waste precursor (CFA and GBFS) & & $25 \%$ & $4 \%$ & & $37 \%$ \\
Metakaolin & & & $9 \%$ & $13 \%$ & \\
Fine aggregates & $9 \%$ & $13 \%$ & $19 \%$ & $13 \%$ & $17 \%$ \\
Coarse aggregates & $52 \%$ & $45 \%$ & $48 \%$ & $43 \%$ & $30 \%$ \\
Water & $12 \%$ & $6 \%$ & $4 \%$ & $6 \%$ & $16 \%$ \\
Polypropylene fiber & $0.14 \%$ & $0.14 \%$ & $0.14 \%$ & $0.14 \%$ & $0.14 \%$ \\
\hline
\end{tabular}

Table 4. Properties of the different material mixes.

\begin{tabular}{cccccc}
\hline Material Property & Mix 0 & Mix 1 & Mix 2 & Mix 3 & Mix 4 \\
\hline $\begin{array}{c}\text { Compressive strength } \\
\text { (28 days) }[\mathrm{MPa}]\end{array}$ & 50 & 25 & 37 & 30 & 14 \\
\hline
\end{tabular}

Based on mix designs and material prices, it is possible to present price estimates for the mixes. However, there are some notable uncertainties. For materials that are rarely used in concrete mixes, the price information is not generally available. For example, in this case, recycled aggregates were used in all the mixes, but those aggregates do not have a market price, because they were produced only on laboratory scale. For simplicity, prices of all aggregates were assumed to be similar to sand and gravel. Additionally, the prices in Alibaba.com do not represent material prices in all locations. Therefore, the basic calculations can be used only for preliminary analysis.

Figure 4 presents a visualization of the price ranges of different concrete mixes. The lower boundary for the price range of a mix is simply calculated as the weighted average of the lower boundaries of material prices presented in the previous section. The upper boundary was calculated in an analogous manner.

The cost price range of Mix 4 is analogous to the cost price range of Mix 0 (OPC concrete). For Mix 1 and Mix 0, the ranges partly overlap. This means that under certain conditions, it is possible that the cost price of Mix 1 is closely similar to that of OPC concrete. For Mixes 2 and 3, the price ranges were clearly different when compared with Mix 0 . Therefore, to compete in the markets, these mixes should offer clearly more value to the customers than the Mix 0.

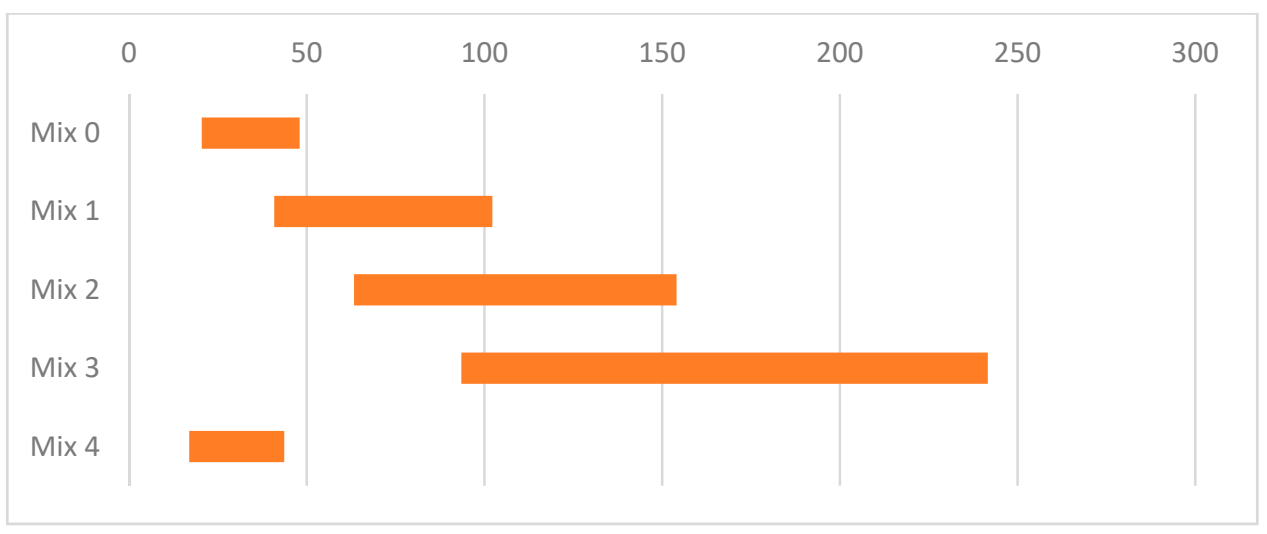

Figure 4. Cost price ranges for different material mixes [USD/t] (wet tonne).

This is a simplified preliminary cost price comparison, but it can be used in determining mixes that are by default clearly more expensive than the basic OPC mix. For example, the use of a potassium-based alkali activator, high activator proportion, and silica fume or 
silica sand anticipate a high-cost price for the mix. In the literature, numerous described mixes are designed for laboratory purposes and are not cost-optimized.

The comparison can be refined to account for the location where the mix is to be prepared. Potential freight can be added to the price estimates, and suppliers can be removed and added according to the possible delivery area. Activators' price ranges can also be narrowed by specifying the required activator characteristics in more detail. In the case project, for example, a higher price and/or freight would have to be applied to coal fly ash, which would clearly increase the price of Mix 4.

If no price information is available for the raw materials, the applicability of this procedure is limited. Notably, only material costs are considered here, while the actual cost price is also affected by manufacturing costs (mixing). The production of geopolymer concrete is somewhat more demanding than OPC concrete because dry materials (including aggregates) have to be dry-mixed, whereas in the production of OPC concrete, the moisture content of the aggregates can vary.

\subsection{The Impact of Carbon Pricing on Cost Prices}

Although it is often mentioned in the literature that geopolymers have the potential to offer $80 \%$ less carbon footprint than OPC concrete, the actual reduction depends on the mix and, in some cases, the carbon footprint of geopolymer concretes can even be higher than OPC concrete [73]. The carbon footprint reduction potentials of the case project mixes are presented in Table 5 based on the LCA performed in this project. The reduction potential is calculated for the mixes, both based on the LCA done in the project (Case 1) and expecting that $\mathrm{CO}_{2}$ emissions of OPC concrete production will decrease by $25 \%$ (Case 2). Mix 4 had the highest reduction potential, and Mix 1 also held some potential even when the $\mathrm{CO}_{2}$ emissions of OPC production decreased. The LCA was conducted assuming local material sourcing. If, for example, fly ash is transported between continents, emissions from transportation should also be taken into account in the calculation.

Table 5. Comparison of carbon footprints of different concrete mixes.

\begin{tabular}{lccccc}
\hline \multicolumn{1}{c}{ Measure } & Mix 0 & Mix 1 & Mix 2 & Mix 3 & Mix 4 \\
\hline Carbon footprint $\left[\mathrm{kg} \mathrm{CO}_{2} / \mathrm{m}^{3}\right]$ & 247 & 119 & 220 & 342 & 5 \\
Carbon footprint $\left[\mathrm{kg} \mathrm{CO}_{2} / \mathrm{t}\right]$ & 107.20 & 51.61 & 95.64 & 148.79 & 2.08 \\
reduction potential compared with OPC & 1 & $52 \%$ & $11 \%$ & $-39 \%$ & $98 \%$ \\
reduction potential compared with OPC & 2 & $20 \%$ & $-11 \%$ & $-48 \%$ & $55 \%$ \\
\hline
\end{tabular}

* Assuming 2,3 t/ $\mathrm{m}^{3}$ density; ${ }^{1}$ current situation; ${ }^{2}$ expecting $25 \%$ reduction in the $\mathrm{CO}_{2}$ emissions of $\mathrm{OPC}$ concrete production.

Figure 5 shows how carbon pricing affects the material cost prices. This calculation assumes that carbon pricing is applied to the total $\mathrm{CO}_{2}$ emissions of the material production. In this case, carbon pricing affects the cost differences of the mixes but does not change the order of the mixes. Mix 4 has a lower cost price than OPC concrete; (however, in the case of Finland, where coal fly ash is more expensive, this would not be the case). Taxation can impact the cost competitivity only when the mixes have a small cost price difference and a large difference in carbon footprint.

This illustration demonstrates that mixes can be categorized according to whether their price difference can be offset by taxation, and it provides a rough estimate of how large cost price differences can be compensated by taxation. However, this is a simplified calculation that does not represent a real starting point in detail. Examples of carbon prices were added to the figure only to present the magnitude of current carbon prices.

In principle, carbon emissions regulation can also have impacts, for example, on transportation costs. However, cement production or binders are the major causes of $\mathrm{CO}_{2}$ emissions during the whole life cycle of concrete constructs; thus, the estimates of the impacts of carbon emissions regulation on the other parts of the life cycle are framed out from the scope of this study. 


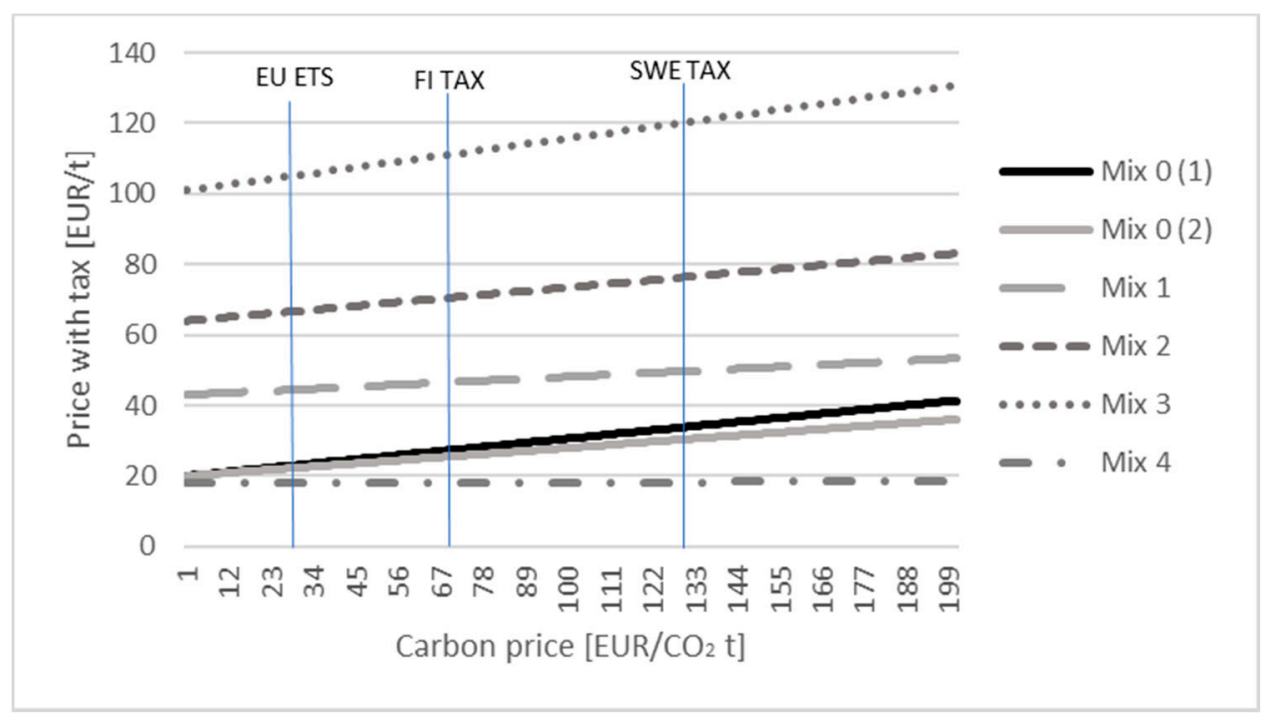

Figure 5. Cost prices of different materials with hypothetical carbon taxes [EUR/t].

\section{Discussion}

The cost-competitiveness of new materials is an imperative factor that determines the potential for their extensive use. So-called geopolymer concretes have been studied considerably in recent years, whereas their material costs have been limitedly studied. This study investigated how the cost-competitiveness of different materials can be assessed and what can be said about the cost-competitiveness of geopolymer concretes at a general level.

This study's approach was to conduct a preliminary cost estimate using only the "quick and dirty" approach to raw material prices alone, which could be refined, for example, by increasing transport and processing costs and refining raw material specifications. However, there are significant cost differences between some mix designs, and some mixes can be exorbitant in practice for commercial exploitation unless a clear in-service cost benefit can be presented compared to competing products.

For some geopolymer mixes, the material prices in the preliminary analysis seem to correspond to the price of traditional concrete. This requires inexpensive raw material choices, the local availability of binder precursors, and a low alkali activator proportion. This can be generalized to other recycled low-carbon concretes.

Carbon taxation cannot be expected to have a significant effect on the price differential between geopolymer concrete and conventional concrete at a general level. This is because in some geopolymer concrete mixes, the carbon footprint is similar to that of traditional concrete; the carbon footprint of OPC concrete can be expected to decrease, and for some geopolymer concrete mixes, the price difference to OPC concrete is exorbitant by default. However, taxation may change the competitive situation in rare cases, where the cost price difference of two mixes is small, but the carbon footprints differ significantly.

This study provides an overview of the cost-competitiveness of recycling-based lowcarbon concretes, and the approach presented can have practical value in mix design. However, this study has some limitations. First of all, this study does not cover all costs, but focuses specifically on the effects of mix designing. On the other hand, this delineation is relevant in practice, because mix design is a determinant to the cost-competitiveness of geopolymer concretes. Secondly, with the approach described, it is not possible to accurately estimate the cost prices of material mixes for which the raw materials are not generally available for purchase. However, in these cases, the market prices of industrially produced side streams can be used as reference values for approximating what price a side stream (requiring similar processing, etc.) could be expected to have when commercially produced. Based on the target price of the material mix, target values can be set for the recycling-based raw materials that are not yet commercially produced. 


\section{Materials and Methods}

The strategic methodological choice in this study was design science, where the aim is to develop tentative solutions to actual problems [74]. In practice, this induces case studies that can be used to answer questions about "why" or "how" [75] (p. 14).

This study was conducted as part of an EU-funded research project titled "Urban Infra Revolution," in which new geopolymer concrete mixes for urban construction were developed and piloted. Furthermore, it aimed to elucidate the market potential of these new materials. In practice, the question of market potential is crystallized into two questions: What are the benefits of using the material?; and how much does it cost? Generally, it is relevant to have a clear transparent process in making cost price estimates, especially when material development is an ongoing process that involves several parties. Therefore, this study has demonstrated a preliminary cost estimation process with illustrative examples provided by the project.

\section{Data Collection and Analysis}

In this study, the focus was on experimenting with an easy and repeatable method for material mix cost price determination. Therefore, the price search focused on Aliababa.com, the largest business to business marketplace in the world. Electronical commerce can be expected to become more widespread and centralized, and therefore the applicability of the approach can be expected to improve in the future. Market price information from other sources than this type service is laborious to collect, the information becomes rapidly obsolete, and its local utilization is limited in any case.

If the production of (geopolymer) concrete is considered in a particular location, the freights of raw materials must of course be considered in the cost estimate. However, one strategy in the geopolymer business is to import technology to geographical areas where the availability of critical side streams is good [76], so in that sense it is not a problem; even if for some materials, the price information is concentrated in certain areas (in this case, China and India). It is useful to get quickly a rough cost estimate, which can be refined, e.g., according to specific geographical areas.

Price information was sought for raw materials that commonly appear in concrete mixes presented in the literature. These data were collected from Alibaba.com, an electronic business shopping site. This service does not support downloading data directly from the system; therefore, a web scraping method was used. Web scraping, also called "parsing" or "web harvesting," means extracting data from websites. It is a form of copying selected visible data from a website, typically into a central local database or spreadsheet, for later retrieval or analysis. In this study, web scraping was conducted using Web Scraper, an extension of Google Chrome. A search was conducted using the material name as a search word. Data rows extracted included the product name, product information, including product description and price range, supplier country, and supplier name. Data were saved in comma-separated values format (csv-format) for analysis in a spreadsheet application. In this phase, the data were also filtered manually to screen out products other than searched material-for example, material processing equipment. Although this price search method has its limitations (e.g., most of the suppliers are from China), it offers easy access to extensive business to business price data. This price search was complemented with price inquiries for coal fly ash and blast furnace slag suppliers in Finland by email and phone.

Carbon dioxide emission estimates for concrete materials were collected from the scientific literature and calculated using $\mathrm{GaBi}$, a database for LCA calculation. The LCA calculation was extensively described by Abdulkareem et al. [77]. Other necessary information for the calculations was collected from the literature, e.g., the current carbon prices from public sources and the material mixes from a company report.

The data were used for presenting illustrative examples of material mix cost prices. The analysis aimed to answer the questions concerning material costs that were raised by different parties during the project, such as what is the cost price of new concrete mixes compared to competing concrete mixes? How much would the carbon tax have to be to 
even out the price difference between OPC concrete and geopolymer concrete? How does the location of production affect the cost-competitiveness of different concretes? All of these are relevant questions when considering the commercialization of geopolymer technology.

Author Contributions: Conceptualization, A.R.; methodology, A.R.; validation, A.R. and J.H.; investigation, A.R. and M.A.; data curation, A.R. and M.A.; writing-original draft preparation, A.R. and J.H.; visualization A.R. All authors have read and agreed to the published version of the manuscript.

Funding: This research was funded by European Regional Development Fund, European Union via the Urban Innovative Actions initiative for co-financing the Urban Infra Revolution project under project number UIA02-155. The APC was funded by VITAKO ry.

Institutional Review Board Statement: Not applicable.

Informed Consent Statement: Not applicable.

Data Availability Statement: The data presented in this study are available on request from the corresponding author. The data are not publicly available due to impracticality of the data sharing services available.

Conflicts of Interest: The authors declare no conflict of interest. The funders had no role in the design of the study; in the collection, analyses, or interpretation of data; in the writing of the manuscript, or in the decision to publish the results.

\section{References}

1. Miller, S.A.; Horvath, A.; Monteiro, P.J.M. Readily implementable techniques can cut annual $\mathrm{CO}_{2}$ emissions from the production of concrete by over 20\%. Environ. Res. Lett. 2016, 11, 074029. [CrossRef]

2. Imbabi, M.S.; Carrigan, C.; McKenna, S. Trends and developments in green cement and concrete technology. Int. J. Sustain. Built Environ. 2012, 1, 194-216. [CrossRef]

3. Van Deventer, J.S.J.; Provis, J.L.; Duxson, P. Technical and commercial progress in the adoption of geopolymer cement. Miner. Eng. 2012, 29, 89-104. [CrossRef]

4. Miller, S.A.; John, V.M.; Pacca, S.A.; Horvath, A. Carbon dioxide reduction potential in the global cement industry by 2050. Cem. Concr. Res. 2018, 114, 115-124. [CrossRef]

5. Salas, D.A.; Ramirez, A.D.; Rodríguez, C.R.; Petroche, D.M.; Boero, A.J.; Duque-Rivera, J. Environmental impacts, life cycle assessment and potential improvement measures for cement production: A literature review. J. Clean. Prod. 2016, 113, 114-122. [CrossRef]

6. Cembureau. Reaching Climate Neutrality along the Cement and Concrete Value Chain by 2050—Cementing the European Green Deal. 2020. Available online: https:/ / cembureau.eu/media/w0lbouva/cembureau-2050-roadmap_executive-summary_finalversion_web.pdf (accessed on 8 July 2020).

7. Laurent, A.; Bakas, I.; Clavreul, J.; Bernstad, A.; Niero, M.; Gentil, E.; Hauschild, M.Z.; Christensen, T.H. Review of LCA studies of solid waste management systems-Part I: Lessons learned and perspectives. Waste Manag. 2014, 34, 573-588. [CrossRef]

8. SFS-EN ISO 14040 Environmental Management_Life Cycle Assessment_Principles and Framework 2006; Finnish Standards Association ry: Helsinki, Finland, 2006.

9. Singh, B.; Ishwarya, G.; Gupta, M.; Bhattacharyya, S.K. Geopolymer concrete: A review of some recent developments. Constr. Build. Mater. 2015, 85, 78-90. [CrossRef]

10. Hasnaoui, A.; Ghorbel, E.; Wardeh, G. Optimization approach of granulated blast furnace slag and metakaolin based geopolymer mortars. Constr. Build. Mater. 2019, 198, 10-26. [CrossRef]

11. Zhao, S.; Fan, J.; Sun, W. Utilization of iron ore tailings as fine aggregate in ultra-high performance concrete. Constr. Build. Mater. 2014, 50, 540-548. [CrossRef]

12. İlker, B.T.; Selim, Ş. Properties of concretes produced with waste concrete aggregate. Cem. Concr. Res. 2004, 34, 1307-1312. [CrossRef]

13. Yliniemi, J.; Nugteren, H.; Illikainen, M.; Tiainen, M.; Weststrate, R.; Niinimäki, J. Lightweight aggregates produced by granulation of peat-wood fly ash with alkali activator. Int. J. Miner. Process. 2016, 149, 42-49. [CrossRef]

14. Suomen Erityisjäte Oy Lehdistötiedote "Yli 300000 Tonnia Pohjakuonaa Hyötykäyttöön". Available online: http: / / www.erityisjate.fi /yritys / uutiset-ja-ajankohtaiset/?newsid=309\&newstitle=Lehdistötiedote+\%22Yli+300+000+tonnia+ pohjakuonaa+hyötykäyttöön\%22 (accessed on 21 December 2018).

15. Kovář́k, T.; Rieger, D.; Kadlec, J.; Křenek, T.; Kullová, L.; Pola, M.; Bělský, P.; Franče, P.; Říha, J. Thermomechanical properties of particle-reinforced geopolymer composite with various aggregate gradation of fine ceramic filler. Constr. Build. Mater. 2017, 143, 599-606. [CrossRef]

16. Aldred, J.; Day, J. Is geopolymer concrete a suitable alternative to traditional concrete. In Proceedings of the 37th Conference on Our World in Concrete, Singapore, 29-31 August 2012. 
17. Albitar, M.; Mohamed Ali, M.S.; Visintin, P.; Drechsler, M. Durability evaluation of geopolymer and conventional concretes. Constr. Build. Mater. 2017, 136, 374-385. [CrossRef]

18. Valencia Saavedra, W.G.; Mejía de Gutiérrez, R. Performance of geopolymer concrete composed of fly ash after exposure to elevated temperatures. Constr. Build. Mater. 2017, 154, 229-235. [CrossRef]

19. Yang, K.-H.; Lee, K.-H.; Song, J.-K.; Gong, M.-H. Properties and sustainability of alkali-activated slag foamed concrete. J. Clean. Prod. 2014, 68, 226-233. [CrossRef]

20. Chan, C.C.S.; Thorpe, D.; Islam, M. An evaluation of life long fly ash based geopolymer cement and ordinary Portland cement costs using extended life cycle cost method in Australia. In Proceedings of the 2015 IEEE International Conference on Industrial Engineering and Engineering Management (IEEM), Singapore, 6-9 December 2015; pp. 52-56.

21. Vilamová, S.; Piecha, M. Economic evaluation of using of geopolymer from coal fly ash in the industry. Acta Montan. Slovaca 2016, 21, 139-145.

22. Ostwal, T.; Chitawadagi, M.V. Experimental investigations on strength, durability, sustainability \& economic characteristics of geo-polymer concrete blocks. IJRET Int. J. Res. Eng. Technol. 2014, 3, 115-122.

23. SFS-EN 197-1 Cement. Part 1: Composition, Specifications and Conformity Criteria for Common Cements 2012; Finnish Standards Association ry: Helsinki, Finland, 2012.

24. Jamieson, E.J.; Penna, B.; van Riessen, A.; Nikraz, H. The development of Bayer derived geopolymers as artificial aggregates. Hydrometallurgy 2017, 170, 74-81. [CrossRef]

25. Sun, T.; Chen, J.; Lei, X.; Zhou, C. Detoxification and immobilization of chromite ore processing residue with metakaolin-based geopolymer. J. Environ. Chem. Eng. 2014, 2, 304-309. [CrossRef]

26. Torres-Carrasco, M.; Puertas, F. Waste glass in the geopolymer preparation. Mechanical and microstructural characterisation. J. Clean. Prod. 2015, 90, 397-408. [CrossRef]

27. Yliniemi, J.; Kinnunen, P.; Karinkanta, P.; Illikainen, M.; Yliniemi, J.; Kinnunen, P.; Karinkanta, P.; Illikainen, M. Utilization of Mineral Wools as Alkali-Activated Material Precursor. Materials 2016, 9, 312. [CrossRef]

28. Bernal, S.A.; Rodríguez, E.D.; Mejia De Gutiérrez, R.; Provis, J.L.; Delvasto, S. Activation of metakaolin/slag blends using alkaline solutions based on chemically modified silica fume and rice husk ash. Waste Biomass Valorization 2012, 3, 99-108. [CrossRef]

29. Wu, Y.-H.; Huang, R.; Tsai, C.-J.; Lin, W.-T. Recycling of Sustainable Co-Firing Fly Ashes as an Alkali Activator for GGBS in Blended Cements. Materials 2015, 8, 784-798. [CrossRef]

30. Heidrich, C.; Sanjayan, J.; Berndt, M.L.; Foster, S. Pathways and barriers for acceptance and usage of geopolymer concrete in mainstream construction. In Proceedings of the 2015 World of Coal Ash (WOCA) Conference, Nasvhille, TN, USA, 5-7 May 2015.

31. RamaC References-RamaC. Available online: https://ramacreadymix.nl/en/references/ (accessed on 21 February 2020).

32. Provis, J.L.; van Deventer, J.S.J. Alkali Activated Materials: State-of-the-Art Report, RILEM TC 224-AAM; Springer: Dordrecht, The Netherlands, 2013.

33. van Deventer, J.S.J.; Provis, J.L.; Duxson, P.; Brice, D.G. Chemical Research and Climate Change as Drivers in the Commercial Adoption of Alkali Activated Materials. Waste Biomass Valorization 2010, 1, 145-155. [CrossRef]

34. Wagners EFC Geopolymer Pavements in Wellcamp Airport I Our Projects I Main I Wagner. Available online: https: / / www.wagner. com.au/main/our-projects/efc-geopolymer-pavements-in-wellcamp-airport (accessed on 5 February 2020).

35. Geocement.in. Kiran Global Green Geocement. Available online: http://www.geocement.in/product_details.php?id=25 (accessed on 21 February 2020).

36. Nu-Core Nu-Core ${ }^{\circledR A 2 F R ~ N o n-C o m b u s t i b l e ~ I ~ A C M ~ A 2 F R ~ F i r e ~ R a t i n g, ~ F i r e ~ P r o o f, ~ N o n-C o m b u s t i b l e, ~ F i r e ~ R e t a r d a n t, ~ F i r e ~}$ Rated I Products I Nu-Core. Available online: http: / / nu-core.com.au/nucore-fr-plus-architectural-grade-fire-rated/ (accessed on 21 February 2020).

37. Geopolymersolutions COLD FUSION CONCRETE®-FP250/Geopolymer Solutions. Available online: https://www. geopolymertech.com/fireproofing/cold-fusion-concrete-fp250/ (accessed on 5 February 2020).

38. Sinnotec SINNOTEC - Sinnotec - Concrete Sealing und Concrete Protection-WHG-Tightened for HBV- und LAU-facilities-We Care about Concrete! Available online: http:/ / www.sinnotec.eu/Sinnotec-Concrete-Sealing-und-Concrete-Protection-WHGtightened-for-HBV-und-LAU-facilities / (accessed on 21 February 2020).

39. Wagners Pinkenba Wharf I Our Projects I Main I Wagner. Available online: https:/ /www.wagner.com.au/main/our-projects / pinkenba-wharf/ (accessed on 21 February 2020).

40. Wagners North Haven Boat Ramp I Our Projects I Main I Wagner. Available online: https:/ /www.wagner.com.au/main/ourprojects/north-haven-boat-ramp/ (accessed on 21 February 2020).

41. Schlumberger Cementing Services I Schlumberger. Available online: https://www.slb.com/drilling/drilling-fluids-and-wellcementing/well-cementing (accessed on 21 February 2020).

42. CLOCKSPRING I NRI GeoSpray®AMS Geopolymer-ClockSpring I NRI ClockSpring I NRI. Available online: https: / www clockspring.com/product/geospray-ams-geopolymer/ (accessed on 21 February 2020).

43. Omar Sore, S.; Messan, A.; Prud'homme, E.; Escadeillas, G.; Tsobnang, F. Stabilization of compressed earth blocks (CEBs) by geopolymer binder based on local materials from Burkina Faso. Constr. Build. Mater. 2018, 165, 333-345. [CrossRef]

44. Habert, G.; Ouellet-Plamondon, C. Recent update on the environmental impact of geopolymers. RILEM Tech. Lett. 2016, 1, 17. [CrossRef] 
45. McLellan, B.C.; Williams, R.P.; Lay, J.; van Riessen, A.; Corder, G.D. Costs and carbon emissions for geopolymer pastes in comparison to ordinary portland cement. J. Clean. Prod. 2011, 19, 1080-1090. [CrossRef]

46. Ma, C.-K.; Awang, A.Z.; Omar, W. Structural and material performance of geopolymer concrete: A review. Constr. Build. Mater. 2018, 186, 90-102. [CrossRef]

47. Mehta, A.; Siddique, R. An overview of geopolymers derived from industrial by-products. Constr. Build. Mater. 2016, 127, 183-198. [CrossRef]

48. Reddy, M.S.; Dinakar, P.; Rao, B.H. A review of the influence of source material's oxide composition on the compressive strength of geopolymer concrete. Microporous Mesoporous Mater. 2016, 234, 12-23. [CrossRef]

49. Ng, C.; Alengaram, U.J.; Wong, L.S.; Mo, K.H.; Jumaat, M.Z.; Ramesh, S. A review on microstructural study and compressive strength of geopolymer mortar, paste and concrete. Constr. Build. Mater. 2018, 186, 550-576. [CrossRef]

50. World Bank Carbon Pricing Dashboard IUp-to-Date Overview of Carbon Pricing Initiatives. Available online: https:// carbonpricingdashboard.worldbank.org/ (accessed on 4 September 2020).

51. Companies and emissions: Carbon copy. Economist 2013, 322, 70.

52. Bai, Q.; Gong, Y.; Jin, M.; Xu, X. Effects of carbon emission reduction on supply chain coordination with vendor-managed deteriorating product inventory. Int. J. Prod. Econ. 2019, 208, 83-99. [CrossRef]

53. Fareeduddin, M.; Hassan, A.; Syed, M.N.; Selim, S.Z. The impact of carbon policies on closed-loop supply chain network design. Procedia CIRP 2015, 26, 335-340. [CrossRef]

54. Jin, M.; Granda-Marulanda, N.A.; Down, I. The impact of carbon policies on supply chain design and logistics of a major retailer. J. Clean. Prod. 2014, 85, 453-461. [CrossRef]

55. Xu, J.; Chen, Y.; Bai, Q. A two-echelon sustainable supply chain coordination under cap-and-trade regulation. J. Clean. Prod. 2016, 135, 42-56. [CrossRef]

56. Zakeri, A.; Dehghanian, F.; Fahimnia, B.; Sarkis, J. Carbon pricing versus emissions trading: A supply chain planning perspective. Int. J. Prod. Econ. 2015, 164, 197-205. [CrossRef]

57. Li, D.; Wang, X.; Chan, H.K.; Manzini, R. Sustainable food supply chain management. Int. J. Prod. Econ. 2014, 152, 1-8. [CrossRef]

58. Li, J.; Su, Q.; Ma, L. Production and transportation outsourcing decisions in the supply chain under single and multiple carbon policies. J. Clean. Prod. 2017, 141, 1109-1122. [CrossRef]

59. Guo, J.; Bao, Y.; Wang, M. Steel slag in China: Treatment, recycling, and management. Waste Manag. 2018, 78, 318-330. [CrossRef]

60. Luo, Y.; Wu, Y.; Ma, S.; Zheng, S.; Zhang, Y.; Chu, P.K. Utilization of coal fly ash in China: A mini-review on challenges and future directions. Environ. Sci. Pollut. Res. 2021, 28, 18727-18740. [CrossRef] [PubMed]

61. Ganesan, N.; Abraham, R.; Deepa Raj, S. Durability characteristics of steel fibre reinforced geopolymer concrete. Constr. Build. Mater. 2015, 93, 471-476. [CrossRef]

62. Khan, M.Z.N.; Hao, Y.; Hao, H.; Shaikh, F.U.A. Mechanical properties of ambient cured high strength hybrid steel and synthetic fibers reinforced geopolymer composites. Cem. Concr. Compos. 2018, 85, 133-152. [CrossRef]

63. Al-mashhadani, M.M.; Canpolat, O.; Aygörmez, Y.; Uysal, M.; Erdem, S. Mechanical and microstructural characterization of fiber reinforced fly ash based geopolymer composites. Constr. Build. Mater. 2018, 167, 505-513. [CrossRef]

64. Vijai, K.; Kumutha, R.; Vishnuram, B.G. Effect of Inclusion of Steel Fibres on the Properties of Geopolymer Concrete Composites. Asian J. Civ. Eng. (Build. Hous.) 2012, 13, 381-389.

65. Vijai, K.; Kumutha, R.; Vishnuram, B.G. Properties of Glass Fibre Reinforced Geopolymer Concrete Composites. Asian J. Civ. Eng. (Build. Hous.) 2012, 13, 511-520.

66. Nematollahi, B.; Sanjayan, J.; Chai, J.X.H.; Lu, T.M. Properties of Fresh and Hardened Glass Fiber Reinforced Fly Ash Based Geopolymer Concrete. Key Eng. Mater. 2014, 594-595, 629-633. [CrossRef]

67. Ohno, M.; Li, V.C. An integrated design method of Engineered Geopolymer Composite. Cem. Concr. Compos. 2018, 88, 73-85. [CrossRef]

68. Behera, P.; Baheti, V.; Militky, J.; Louda, P. Elevated temperature properties of basalt microfibril filled geopolymer composites. Constr. Build. Mater. 2018, 163, 850-860. [CrossRef]

69. Li, W.; Xu, J. Mechanical properties of basalt fiber reinforced geopolymeric concrete under impact loading. Mater. Sci. Eng. A 2009, 505, 178-186. [CrossRef]

70. Nematollahi, B.; Vijay, P.; Sanjayan, J.; Nazari, A.; Xia, M.; Naidu Nerella, V.; Mechtcherine, V.; Nematollahi, B.; Vijay, P.; Sanjayan, J.; et al. Effect of Polypropylene Fibre Addition on Properties of Geopolymers Made by 3D Printing for Digital Construction. Materials 2018, 11, 2352. [CrossRef]

71. Panda, B.; Paul, S.C.; Hui, L.J.; Tay, Y.W.D.; Tan, M.J. Additive manufacturing of geopolymer for sustainable built environment. J. Clean. Prod. 2017, 167, 281-288. [CrossRef]

72. Paul, S.C.; Tay, Y.W.D.; Panda, B.; Tan, M.J. Fresh and hardened properties of 3D printable cementitious materials for building and construction. Arch. Civ. Mech. Eng. 2018, 18, 311-319. [CrossRef]

73. Abdulkareem, M.; Havukainen, J.; Horttanainen, M. How environmentally sustainable are fibre reinforced alkali-activated concretes? J. Clean. Prod. 2019, 236, 117601. [CrossRef]

74. Van Aken, J.; Chandrasekaran, A.; Halman, J. Conducting and publishing design science research: Inaugural essay of the design science department of the Journal of Operations Management. J. Oper. Manag. 2016, 47-48, 1-8. [CrossRef] 
75. Yin, R.K. Case Study Research: Design and Methods, 5th ed.; SAGE: Thousand Oaks, CA, USA, 2014.

76. Karttunen, E.; Tsytsyna, E.; Lintukangas, K.; Rintala, A.; Abdulkareem, M.; Havukainen, J.; Nuortila-Jokinen, J. Toward environmental innovation in the cement industry: A multiple-case study of incumbents and new entrants. J. Clean. Prod. 2021, 314, 127981. [CrossRef]

77. Abdulkareem, M.; Havukainen, J.; Nuortila-Jokinen, J.; Horttanainen, M. Life cycle assessment of a low-height noise barrier for railway traffic noise. J. Clean. Prod. 2021. submitted. 